Jurnal Tanah dan Air (Soil and Water Journal)

ISSN: 1411-5719(p): 2655-500X (e), Volume 15 Nomor 2 (Desember 2018): 93 - 102 (http://jurnal.upnyk.ac.id/index.php/jta/index)

\title{
UJI AKTIVITAS DEKOMPOSISI DARI BEBERAPA INOKULUM KOMERSIAL PADA BERAGAI JENIS BAHAN BERDASARKAN JUMLAH CO 2 YANG TERBENTUK
}

\section{(DECOMPOSITION ACTIVITIES TEST OF SOME COMMERCIAL INOCULUMS ON VARIOUS TYPES OF MATERIALS BASED ON THE GENERATED AMOUNT OF CO $\left.\mathrm{C}_{2}\right)$}

\author{
Yanisworo Wijaya Ratih ${ }^{2 *)}$, Dessy Apriyani Sohilait ${ }^{1)}$, dan R. Agus Widodo ${ }^{2)}$ \\ 1) Prodi Agroteknologi, Universitas Pembangunan Nasional Veteran Yogyakarta \\ 2) Prodi Ilmu Tanah, Universitas Pembangunan Nasional Veteran Yogyakarta \\ ${ }^{*}$ Corresponding author E - mail: yaniswororatih63b@gmail.com
}

\begin{abstract}
The decomposition of organic matter is a biological process that involves microbial activity. Degradation activity can be represented based on the amount of $\mathrm{CO}_{2}$ produced. Activity observations can be used as a basis for improving decomposition processes, such as the composting. This research was conducted to determine the pattern of $\mathrm{CO}_{2}$ formation during incubation, the total $\mathrm{CO}_{2}$ produced after incubation, and changes in the $\mathrm{C}$ and $\mathrm{N}$ levels of the material after incubation. The research was conducted using a completely randomized design (CRD) 2 factors. The first factor is the type of substrate which consists of three levels, namely paddy straw (S1), water hyacinth (S2), and soybean litter (S3). The second factor is the type of inoculum, namely EM-4 (I1), Promi (I2), and Stardec (I3), in order to obtain nine treatment combinations. The decomposition process was carried out for 8 weeks. The parameters which were analysis were the amount of $\mathrm{CO}_{2}$, levels of $\mathrm{C}$ and $\mathrm{N}$ materials and the $\mathrm{C} / \mathrm{N}$ ratio. $\mathrm{CO}_{2}$ was analyzed using the titration method, $\mathrm{C}$ using the Walkley and Black method, while $\mathrm{N}$ using the Kjeldahl method. The results showed that the formation of $\mathrm{CO}_{2}$ from each treatment reached a maximum in the first week of observation, the highest total $\mathrm{CO}_{2}$ in the straw and soybean litter substrate was found in the substrate inoculated with Stardec (I3) and EM-4, respectively. The decomposition ability of the three inoculums was tested on a low water hyacinth substrate. The decomposition process resulted in a decrease in $\mathrm{C}$ and $\mathrm{N}$ levels.
\end{abstract}

Keywords: $\mathrm{CO}_{2}$, paddy straw, water hyacinth, soybean litter, inoculums

\begin{abstract}
ABSTRAK
Dekomposisi atau perombakan bahan organik merupakan proses biologi yang melibatkan aktivitas mikrobia. Aktivitas perombakan dapat direpresentasikan berdasarkan jumlah $\mathrm{CO}_{2}$ yang dihasilkan. Pengamatan aktivitas dapat digunakan sebagai dasar perbaikan proses dekomposisi, seperti proses pengomposan. Penelitian ini dilakukan untuk mengetahui pola pembentukan $\mathrm{CO}_{2}$ selama inkubasi, total $\mathrm{CO}_{2}$ yang dihasilkan setelah inkubasi, serta perubahan kadar $\mathrm{C}$ dan $\mathrm{N}$ bahan setelah mengalami perombakan. Penelitian dilakukan menggunakan Rancangan Acak Lengkap (RAL) 2 faktor. Faktor pertama berupa jenis substrat yang terdri atas tiga aras, yaitu Jerami padi (S1), Enceng gondok (S2), dan Seresah Kedelai (S3). Faktor kedua berupa jenis inokulum, yaitu EM-4 (I1), Promi (I2), dan Stardec (I3), sehingga diperoleh sembilan kombinasi perlakuan. Proses dekomposisi dilakukan selama 8 minggu. Parameter yang diamati meliputi
\end{abstract}


jumlah $\mathrm{CO}_{2}$, kadar $\mathrm{C}$ dan $\mathrm{N}$ bahan serta $\mathrm{C} / \mathrm{N}$ ratio. $\mathrm{CO}_{2}$ dianalisis menggunakan metode titrasi, $\mathrm{C}$ menggunakan metode Walkley and Black, sedangkan $\mathrm{N}$ menggunakan metode Kjeldahl. Hasil penelitian menunjukkan bahwa pembentukan $\mathrm{CO}_{2}$ dari masing-masing perlakuan mencapai maksimum pada pengamatan minggu pertama, total $\mathrm{CO}_{2}$ tertinggi pada substrat jerami dan seresah kedelai berturut-turut terdapat pada substrat yang diinokulasi dengan Stardec (I3) dan EM-4. Kemampuan dekomposisi ke tiga inokulum yang diuji pada substrat eceng gondok rendah. Proses dekomposisi mengakibatkan penurunan kadar $\mathrm{C}$ dan $\mathrm{N}$.

Kata kunci: aktivitas, $\mathrm{CO}_{2}$, jerami padi, seresah kedelai, enceng gondok, inokulum

\section{PENDAHULUAN}

Dekomposisi atau perombakan bahan organik merupakan proses biologi yang melibatkan aktivitas beberapa jenis mikrobia. Selama proses dekomposisi mikrobia memanfaatkan bahan organik sebagai sumber nutrient dan energi. Dekomposer utama dalam perombakan bahan adalah jamur dan bakteri. Mereka mengeluarkan ensim hidrolitik ekstraselular untuk mengkatalisir dekomposisi bahan organik. Secara umum dekomposisi bahan organic $\left(\mathrm{C}_{\mathrm{a}} \mathrm{H}_{\mathrm{b}} \mathrm{O}_{\mathrm{c}} \mathrm{N}_{\mathrm{d}}\right)$ oleh mikrobia dapat digambarkan dengan menggunakn persamaan berikut:

$$
\left.\mathrm{C}_{\mathrm{a}} \mathrm{H}_{b} \mathrm{O}_{\mathrm{c}} \mathrm{N}_{\mathrm{d}}+\mathrm{xO}_{2} \rightarrow \mathrm{aCO}_{2}+\mathrm{zH}_{2} \mathrm{O}+\mathrm{yNH}_{4}^{+}+\mathrm{X}+\Delta \mathrm{H} \ldots \ldots . .1\right)
$$

Dimana $\triangle \mathrm{H}$ adalah panas yang dihasilkan, $X$ adalah biomassa mikrobia, dan $\mathrm{O}_{2}, \mathrm{CO}_{2}$ dan $\mathrm{NH}_{4}{ }^{+}$berturut-turut adalah oksigen, karbon dioksida dan ammonium.

Pelepasan $\mathrm{CO}_{2}$ pada dekomposisi oleh mikrobia dikenal sebagai proses respirasi. Secara spesifik peristiwa respirasi dijumpai pada dekomposisi karbohidrat seperti amilosa dan selulosa. Polimer amilosa maupun selulosa terhidrolisis menjadi monomernya, berupa glukosa. Selanjutnya glukosa terdekomposisi sehingga dihasilkan $\mathrm{CO}_{2}, \mathrm{H}_{2} \mathrm{O}$ dan energi sepert persamaan berikut ini:

$$
\left.\mathrm{C}_{6} \mathrm{H}_{12} \mathrm{O}_{6}+6 \mathrm{O}_{2} \rightarrow 6 \mathrm{CO}_{2}+6 \mathrm{H}_{2} \mathrm{O}+\text { energi } \ldots \ldots \ldots . .2\right)
$$

Dari persamaan 1) dapat diketahui bahwa dekomposisi bahan organik mengakibatkan mineralisasi karbon dalam bentuk $\mathrm{CO}_{2}$ dan nitrogen dalam bentuk ammonium. Persamaan 1) dan 2) juga menunjukkan bahwa aktivitas perombakan dapat direpresentasikan berdasarkan jumlah $\mathrm{O}_{2}$ yang dibutuhkan, $\mathrm{CO}_{2}$ yang dihasilkan maupun panas yang dilepas (Barrena-Gómez et al., 2006). Di antara ketiga parameter di atas, yang sering digunakan untuk menguji aktivitas dekomposisi bahan organik adalah jumlah $\mathrm{CO}_{2}$ yang dihasilkan, karena secara teknis relative lebih mudah dan hasilnya dapat dipertanggungjawabkan. Pengamatan aktivitas menarik untuk dilakukan karena dapat digunakan sebagai dasar perbaikan dekomposisi suatu bahan, seperti pada proses pengomposan.

Penelitian ini dilakukan untuk menguji aktivitas dekomposisi beberapa inoculum komersial yang sering digunakan dalam proses pengomposan. Inokulum komersial yang digunakan adalah EM4, Strardec dan Promi. EM4 dipilih karena paling sering digunakan pada pembuatan kompos dan memiliki jenis bakteri yang sangat bervariasi. Bioaktivator Stardec dipilih karena mengandung mikroba yang mempunyai kemampuan tinggi dalam merombak lignin dan selulosa, sedangkan bioaktivator Promi dipilih 
karena disamping mengandung jasad perombak juga mengandung jasad pelarut hara yang terikat.

Bahan yang diujikan adalah jerami padi, eceng gondok, dan seresah kedelai. Jerami padi dan seresah kedelai dipilih karena bahan tersebut banyak dijumpai dan sering digunakan sebagai bahan baku dalam proses pengomposan. Enceng gondok digunakan karena tanaman tersebut berpotensi sebagai bahan dasar pengomposan mengingat biomasanya yang banyak akibat pertumbuhannya yang cepat, bahkan dikenal sebagai gulma air. Pemilihan bahan penelitian juga didasarkan pada karakteristik kimiawi yang mempengaruhi proses dekomposisi, yaitu kadar serat berupa selulosa, hemiselulosa dan lignin. Jerami padi mempuyai kadar selulosa dan hemiselulosa berturut turut antara 25-50\% dan 25-30\%, serta kadar lignin dapat mencapai 30\% (Olsson, 2006). Enceng gondok mempunyai kadar selulosa sekitar 30\%, hemiselulosa 28-32\%, dan lignin maksimum mencapai 18\% (Sivasankari dan Ravindran, 2016), sedangkan seresah tanaman legume mepunyai kadar selulosa antara 11-28\% dan lignin maksimum mencapai 16\% (Silva et al., 2008).

Penelitian ini dilakukan untuk mengetahui pola dan total $\mathrm{CO}_{2}$ yang terbentuk selama inkubasi berlangsung dari beberapa inokulum komersial dalam merombak bahan. Diharapkan hasil penelitian ini dapat digunakan sebagai dasar untuk pemilihan bioaktivator yang tepat dalam proses pengomposan, sehingga pengomposan dapat berjalan efisien.

\section{BAHAN DAN METODE}

Metode penelitian disusun dalam Rancangan Acak Lengkap 2 faktor. Faktor pertama berupa jenis substrat yang terdri atas tiga aras, yaitu Jerami (S1), Enceng gondok (S2), dan Seresah Kedelai (S3). Faktor kedua berupa jenis bioaktivator, yaitu EM-4 (I1), Promi (I2), dan Stardec (I3), sehingga diperoleh Sembilan kombinasi perlakuan. Ulangan dilakukan sebanyak tiga kali. Bahan yang digunakan pada penelitian ini adalah Jerami Padi, Seresah Kedelai, Enceng Gondok, EM-4, Stardec, Promi, akuades, SP-36, Urea, $\mathrm{K}_{2} \mathrm{Cr}_{2} \mathrm{O}_{7}, \mathrm{H}_{2} \mathrm{SO}_{4}$, Indikator diphenilamyne, $\mathrm{H}_{3} \mathrm{PO}_{4}$, $\mathrm{FeSO}_{4}$, Asam borat, Indikator Methyl Red, $\mathrm{NaOH}$, Amonium Molibdat, $\mathrm{SnCl}_{2}, \mathrm{HCl}$, $\mathrm{KH}_{2} \mathrm{PO}_{4}$, dan Aquades.

Masing-masing bahan dikeringanginkan kemudian dipotong-potong sehingga berukuran sekitar $3 \mathrm{~cm}$. C/N bahan diatur sebesar 30:1 dengan menambahkan urea. C:P bahan ditentukan sebesar 100:1 dengan menambahkan SP-36. Kadar lengas bahan diatur sebesar $60 \%$ WHC. Sebanyak masing-masing $1 \mathrm{~kg}$ bahan diletakkan dalam wadah, selanjutnya diinokulasi dengan masing-masing inokulum sesuai perlakuan dan dicampur secara merata. Jumlah inoculum yang ditambahkan sesuai dengan dosis yang direkomendasikan produsen, yaitu untuk EM-4, Promi dan Stardec berturut-turut sebesar $1 \mathrm{ml}, 1 \mathrm{~g}$, dan $0,25 \mathrm{~g}$. Wadah yang sudah berisi bahan ditutup rapat menggunakan plastik yang dilubangi menggunakan lidi. Selanjutnya dilakukan inkubasi selama 2 bulan. Kelengasan dipertahankan pada kondisi $60 \%$ WHC dengan menimbang bahan. Apabila terjadi penurunan berat maka ditambahkan dengan akuades dengan jumlah yang sama dengan jumlah penurunan berat. Setiap satu minggu dilakukan pengadukan bahan.

Parameter yang diamati meliputi pembentukan $\mathrm{CO}_{2}$, C-Organik, dan $\mathrm{N}$ total. $\mathrm{CO}_{2}$ dianalisis menggunakan metode titrasi (Ratih et al., 2018), dilakukan seminggu sekali. 
Untuk pengamatan pembentukan $\mathrm{CO}_{2}$, masing-masing bahan ditimbang seberat $10 \mathrm{~g}$ dan dimasukkan ke dalam botol reagen volume $350 \mathrm{ml}$. Ke dalam wadah diletakkan botol plastik terbuka bervolume sekitar 50ml yang diisi dengan $20 \mathrm{ml} \mathrm{NaOH} \mathrm{0,2} \mathrm{N}$. Botol reagen ditutup dengan rapat, selanjutnya diinkuasikan selama 5 jam. $\mathrm{CO}_{2}$ yang terbentuk ditentukan dengan cara menitrasi sisa $\mathrm{NaOH}$ yang tidak bereaksi dengan $\mathrm{CO}_{2}$ menggunakan asam oksalat 0,5 N. Blanko dibuat dengan urutan kerja yang sama, namun menggunakan bahan yang sudah disterilkan pada suhu $121^{\circ} \mathrm{C}$, tekanan 2 atmosfer selama 30 menit, menggunakan autoclave. Jumlah $\mathrm{CO}_{2}$ yang terbentuk ditentukan menggunakan rumus berikut:

$\mathrm{CO}_{2}=(\mathrm{ml}$ blangko-ml baku $) \times \mathrm{N}$ oksalat $\left.\mathrm{x} 22\right) \mathrm{mg} / \mathrm{satuan}$ waktu/g bahan .

C-Organik ditentukan menggunakan metode Walkley and Black dan $\mathrm{N}$ ditentukan menggunakan metode Kjeldahl (Eviati dan Sulaeman, 2009). Data kadar C dan N yang diperoleh dalam penelitian dianalisis menggunakan analisis variansi (ANOVA), apabila terdapat beda nyata diuji lebih lanjut menggunakan uji Duncan Multiple Range Test (DMRT) untuk mengetahui perbedaan antar perlakuan.

\section{HASIL DAN PEMBAHASAN}

\section{Pembentukan $\mathrm{CO}_{2}$}

Respirasi merupakan petunjuk aktivitas mikroorganisme dalam dekomposisi suatu bahan/substrat. Tingkat respirasi dapat ditentukan dengan mengukur $\mathrm{CO}_{2}$ yang dihasilkan. Penetapan tingkat respirasi merupakan salah satu metode yang paling sederhana untuk mengukur aktivitas mikroorganisme. Gambar 1 sampai dengan Gambar 3 menunjukkan pembentukan $\mathrm{CO}_{2}$ oleh masing-masing inokulum pada substrat Jerami (S1), Enceng gondok (S2), serta seresah kedelai (S3). Secara umum dapat dilihat bahwa $\mathrm{CO}_{2}$ yang dihasilkan menunjukkan pola yang sama, yaitu nilai maksimum terjadi pada pengamatan minggu pertama, atau hari ke 7. Pada inkubasi satu minggu berikutnya tingkat pembentukan $\mathrm{CO}_{2}$ menurun. Pada inkubasi lebih lanjut, jumlah $\mathrm{CO}_{2}$ yang terbentuk relatif konstan sampai inkubasi minggu ke 8 .

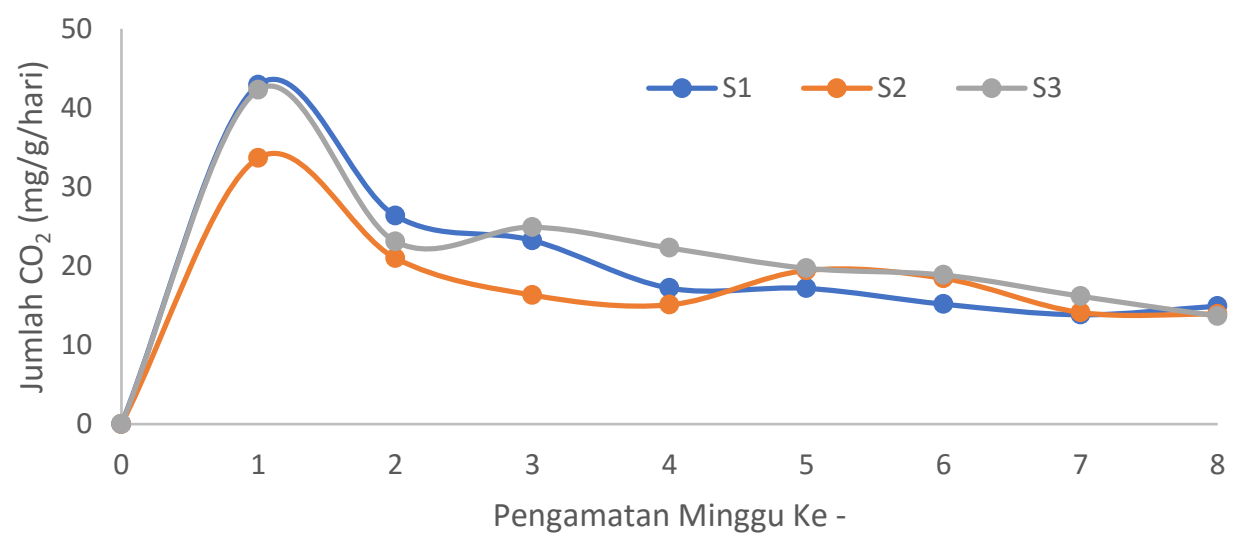

Gambar 1. Pola produksi $\mathrm{CO}_{2}$ dari inokulum EM-4 (I1) pada substrat jerami (S1), eceng gondok (S2), maupun seresah kedelai (S3) 
Fenomena tersebut menunjukkan bahwa aktivitas perombakan yang tertinggi dari masing-masing inokulum terjadi pada fase awal inkubasi (minggu pertama). Pada fase awal senyawa karbon sederhana seperti monosakarida, pati dan lipid akan dimanfaatkan. Setelah inkubasi selama satu minggu, ketersediaan bahan sederhana semakin berkurang, selanjutnya mikroba melakukan dekomposisi bahan yang lebih kompleks, seperti hemiselulosa, selulosa dan lignin. Semakin kompleks bahan maka semakin lambat proses dekomposisi. Hal tersebut karena proses dekomposisi senyawa kompleks melibatkan lebih banyak enzim yang bekerja bersama sama secara komprehensif dan sinergistik. Akibatnya pembentukan $\mathrm{CO}_{2}$ menurun. Dalam proses pengomposan, aktivitas dekomposisi dan respirasi yang tinggi diikuti dengan kenaikan suhu, sehingga proses memasuki fase termofil. Setelah mencapai suhu tinggi, aktivitas mikroba semakin menurun, proses pengomposan memasuki fase pematangan untuk pembentukan humus (Tuomela et al., 2000).

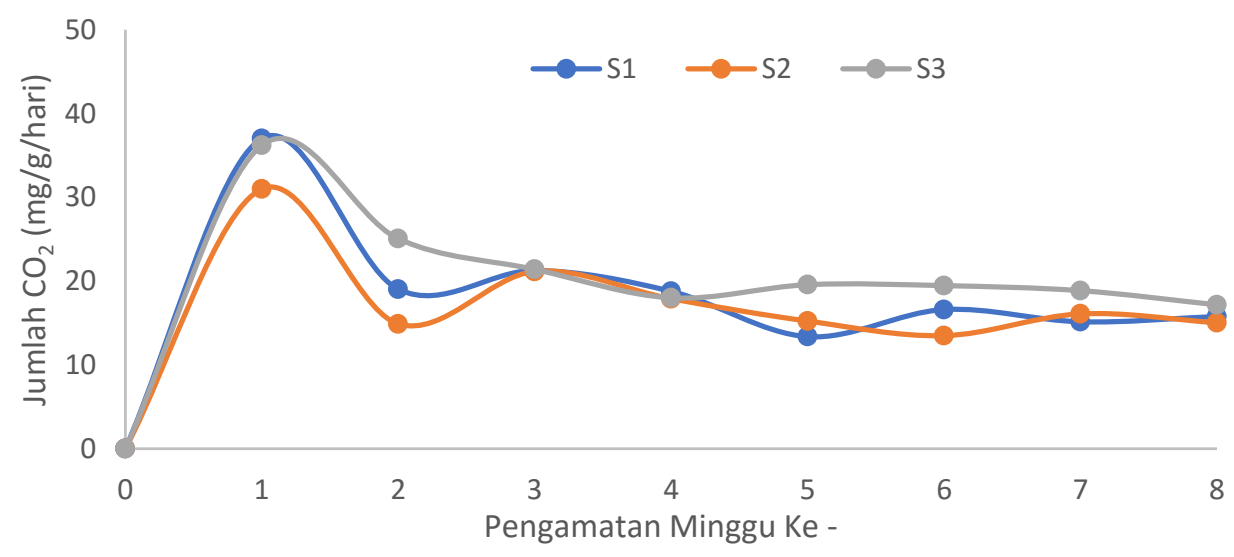

Gambar 2. Pola produksi $\mathrm{CO}_{2}$ dari inokulum Promi (I2) pada substrat jerami (S1), eceng gondok (S2), maupun seresah kedelai (S3)

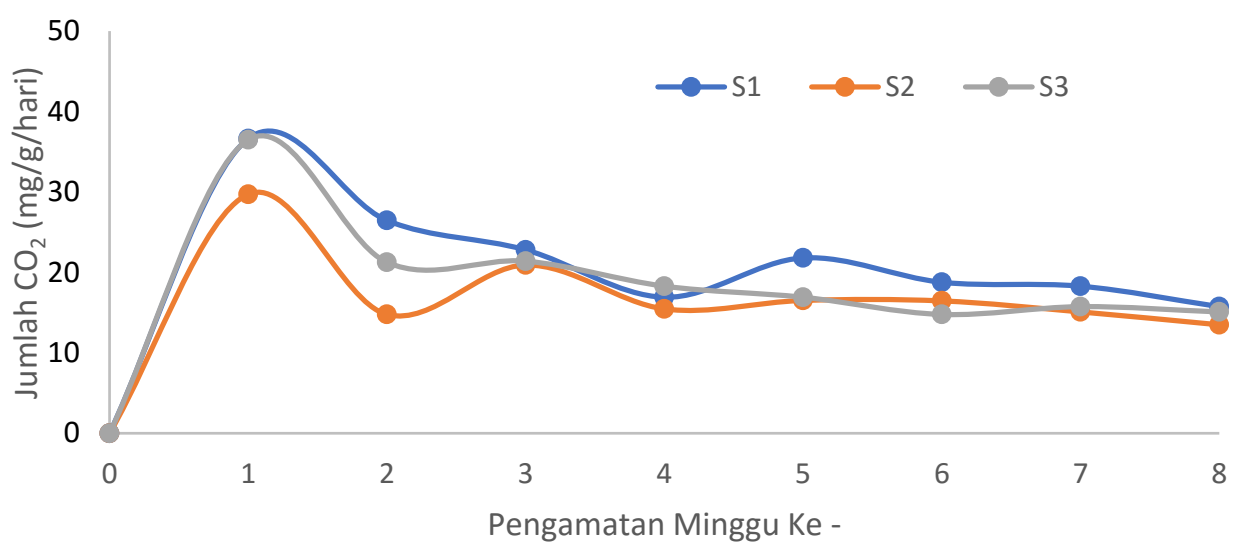

Gambar 3. Pola produksi $\mathrm{CO}_{2}$ dari inokulum Stardec (I3) pada substrat jerami (S1), eceng gondok (S2), maupun seresah kedelai (S3) 
Berdasarkan pada jumlah $\mathrm{CO}_{2}$ yang terbentuk pada setiap pengamatan, maka mikroba yang terdapat dalam Promi (I2) aktivitasnya paling baik pada substrat seresah kedelai (S3) (Gambar 2). Hampir pada setiap pengamatan, $\mathrm{CO}_{2}$ yang terbentuk paling tinggi terdapat pada substrat seresah kedelai (S3). Hasil yang berbeda dijumpai pada inokulum Stardec. Aktivitas mikrobanya paling tinggi terdapat pada substrat jerami (Gambar 3). Inokulum EM-4 (I1) mempunyai aktivitas yang baik pada substrat jerami maupun kedelai (Gambar 1). Fenomena yang menarik justru ditemukan pada substrat eceng gondok (S2), karena semua inokulum yang diuji mempunyai aktivitas perombakan yang rendah.

Apabila aktivitas mikroba perminggu selama inkubasi dari masing-masing inokulum dikaitkan dengan akumulasi jumlah $\mathrm{CO}_{2}$ (jumlah total) yang terbentuk (Gambar 4), maka pada substrat jerami total $\mathrm{CO}_{2}$ yang terbentuk paling tinggi terdapat pada perlakuan S1I3, yaitu jerami (S1) yang diinokulasi dengan Stradec (I3). Jumlah $\mathrm{CO}_{2}$ yang terbentuk mencapai $6179 \mathrm{mg}$. Pada perlakuan $\mathrm{S} 1 \mathrm{II} \mathrm{CO}_{2}$ yang dihasilkan mencapai $5977 \mathrm{mg}$. Pada substrat seresah kedelai (S3), jumlsh $\mathrm{CO}_{2}$ ttertinggi terdapat pada perlakuan S3I1, yaitu yang diinokulasi dengan EM-P. Jumlah $\mathrm{CO}_{2}$ yang dihasilkan mencapai $6334 \mathrm{mg}$, sedangkan inoculum Stardec aktivitasnya paling rendah. Nampaknya inokulum EM-4 mempunyai aktivitas yang baik pada substrat seresah kedelai maupun jerami (meskipun aktivitasnya sedikit lebih rendah dibandingkan dengan Stardec).

Dari data di atas dapat dilihat bahwa ada kesesuaian antara jenis inokulum dengan substratnya. Aktivitas mikroba dalam Stardec paling tinggi pada jerami. Hal ini ada keterkaitan antara komposisi kimiawi jerami dengan jenis mikroba yang terdapat dalam Stardec. Kimiawi jerami didominasi oleh serat, dengan komposisi kadar selulosa dan hemiselulosa berturut turut mencapai antara 25-50\% dan 25$30 \%$, serta kadar lignin dapat mencapai 30\% (Jorgensen and Olsson, 2006). Stardec merupakan inokulum yang di dalamnya mengandung mikroorganisme aerob berupa jamur lignolitik, selulolitik, proteolitik, lipolitik, aminolitik. Mikroba lignolitik mampu memecah lignin sehingga menjadi fragmen yang lebih sederhana. Terpecahnya lignin mengakibatkan selulosa dalam jerami menjadi lebih mudah diakses oleh mikroba selulolitik. Enzim selulase jasad selulolitik mendekomposisi selulosa menjadi glukosa. Selanjutnya glukosa mengalami respirasi sehingga dihasilkan $\mathrm{CO}_{2}$. EM4 mengandung beberapa mikroorganisme utama yaitu bakteri Fotosintetik (Rhodopseudomonas spp.), bakteri asam laktat (Lactobacillus spp.), ragi/yeast (Saccharomyces spp.), Actinomycetes, serta Jamur Fermentasi (Aspergillus dan Penicilium)

Mikroba dalam EM-4 juga mempunyai aktivitas yang relative tinggi pada jerami. Meskipun produsen tidak menyebutkan adanya jasad lignoselulolitik di dalamnya, namun keberadaan aktinomisetes dalam EM-4 memungkinkan senyawa kompleks lignoselulosa dalam jerami terdekomposisi. Pada umumnya aktinomisetes mempunyai kemampuan yang baik dalam merombak serat tanaman, meskipun yang dikenal sebagai jasad perombak lignoselulosa yang baik adalah jamur (Godden et al., 1992; Crawford, 2003). Kemungkinan lain adalah terjadinya sinergisme antara jasad penyusun EM-4 dengan jamur perombak alami yang ada dalam bahan. Secara alami bahan untuk pengomposan dapat mengandung $10^{6} \mathrm{cfu} / \mathrm{g}$ jamur mesofilik serta $10^{3}$ sampai denagn $10^{6}$ jamur termofilik (Tuomela et al., 2000). Jasad termofil terutama berperan dalam perombakan lignoselulosa (Ratih et al., 2018). Semakin lama bahan tersimpan, maka jumlah mikroba alami pendekomposisi semakin 
banyak (Tuomela et al., 2000). Ada kemungkinan bahwa hal seperti itulah yang mengakibatkan aktivitas perombakan mikroba dalam merombak eceng gondok, rendah. Dalam penelitian ini digunakan eceng gondog segar, diambil langsung dari perairan.

Gambar 4 menunjukkan akumulasi $\mathrm{CO}_{2}$ yang dibentuk selama 8 minggu inkubasi. Hasilnya sesuai dengan pola pembentukan $\mathrm{CO}_{2}$ setiap minggu. Dapat dilihat bahwa pada substrat jerami, total $\mathrm{CO}_{2}$ tertinggi terdapat pada bahan yang diinokulasi dengan Stardec (I3), sedangkan pada seresah kedelai (S3), $\mathrm{CO}_{2}$ tertinggi terdapat pada bahan yang diinokulasi dengan EM-4 (I1). Aktivitas ketiga inokulum pada substrat eceng gondok (S2) paling rendah.

\section{Kadar $\mathrm{C}$ dan $\mathrm{C} / \mathrm{N}$ ratio}

Proses dekomposisi mengakibatkan kadar $\mathrm{C}$ bahan berkurang, karena sebagian diubah menjadi $\mathrm{CO}_{2}$. Tabel 1 menunjukkan kadar $\mathrm{C}$ dari maing-masing perlakuan. Hasil analisis menunjukkan bahwa tidak ada interaksi antara jenis bahan dan jenis inokulum. Jenis inokulum tidak berpegaruh nyata terhadap kadar C bahan, sedangkan jenis substrat mempengaruhi kadar C. Kadar C tertinggi terdapat pada substrat eceng gondok dan berbeda nyata dengan $\mathrm{C}$ pada jerami maupun seresah kedelai. $\mathrm{C}$ pada jerami dan seresah kedelai tidak berbeda nyata. Kadar $\mathrm{C}$ tertinggi terdapat pada eceng gondok karena pembentukan $\mathrm{CO}_{2}$ dari aktivitas perombahan pada bahan tersebut juga paling rendah.

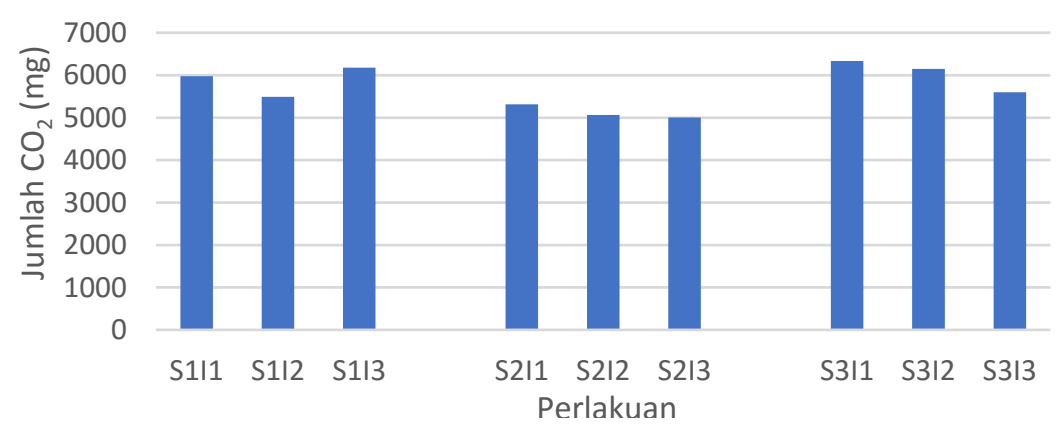

Gambar 4. Total $\mathrm{CO}_{2}$ yang diproduksi selama 8 minggu inkubasi dari masing-masing perlakuan

Tabel 1. C-organik (\%) substrat dari masing-masing perlakuan setelah 8 minggu inkubasi

\begin{tabular}{ccccc}
\hline Limbah/Inokulum & $\mathbf{I}_{\mathbf{1}}$ & $\mathbf{I}_{\mathbf{2}}$ & $\mathbf{I}_{\mathbf{3}}$ & Rerata \\
\hline $\mathrm{S}_{1}$ & 34,25 & 34,25 & 32,24 & $33,58 \mathrm{q}$ \\
$\mathrm{S}_{2}$ & 35,52 & 38,06 & 38,06 & $37,21 \mathrm{p}$ \\
$\mathrm{S}_{3}$ & 34,99 & 30,61 & 32,80 & $32,80 \mathrm{q}$ \\
\hline Rerata & $34,92 \mathrm{a}$ & $34,31 \mathrm{a}$ & $34,37 \mathrm{a}$ & $(-)$ \\
\hline
\end{tabular}

Keterangan: $\mathrm{S}_{1}$ : Jerami; $\mathrm{S}_{2}$ : Enceng gondok; $\mathrm{S}_{3}$ : Seresah Kedelai; $\mathrm{I}_{1}$ : EM4; $\mathrm{I}_{2}$ : Promi; $\mathrm{I}_{3}$ : Stardec; Rerata perlakuan yang diikuti huruf yang sama menunjukkan tidak ada beda nyata pada Uji Berganda Duncan dengan taraf 5\%. Tanda (-) menunjukkan tidak ada interaksi. 
Hasil penelitian ini menujukkan bahwa kadar $\mathrm{N}$ substrat setelah mengalami perombakan mengalami penurunan (Tabel 2). Hal ini mengakibatkan nilai $\mathrm{C} / \mathrm{N}$ ratio tinggi (Tabel 3). Jerami mempunyai kadar C (karbon) rata-rata sebesar 42,68\%. (Harahap, 2008; Haryono, 1989; Ponnamperuna, 1984). Enceng Gondok sebesar 40,15\% (Nurhalimah, 2017, Hajama, 2014, Fitri, 2010) dan seresah kedelai sebesar 47,38\% (Mulyani dan Hidayat, 2010). Sebelum dilakukan inokulasi, C/N ratio diatur sehingga mencapai 30:1, dengan ditambah urea. Dengan demikian, setelah $\mathrm{C} / \mathrm{N}$ diatur, kadar $\mathrm{N}$ pada substrat jerami, eceng gondok, dan seresah kedelai berturut-turut sebesar $1,42 \% ; 1,33 \%$ dan 1,58\%. Setelah inkubasi $\mathrm{N}$ mengalami penurunan, kecuali pada perlakuan S3I3. Kadar N dari masing-masing perlakuan yang mengalami penurunan berkisar antara $0,37 \%$ pada perlakuan S2I1 dan $0,84 \%$ pada S3I2. Hasil analisis data menunjukkan bahwa jenis inokulum maupun jenis substrat tidak mempengaruhi penurunan $\mathrm{N}$ substrat (Tabel 2).

Tabel 2. Kadar N-total substrat dari masing-masing perlakuan setelah 8 minggu inkubasi

\begin{tabular}{ccccc}
\hline Limbah/Inokulum & $\mathbf{I}_{\mathbf{1}}$ & $\mathbf{I}_{\mathbf{2}}$ & $\mathbf{I}_{\mathbf{3}}$ & Rerata \\
\hline $\mathrm{S}_{1}$ & 0,61 & 0,64 & 0,56 & $0,60 \mathrm{p}$ \\
$\mathrm{S}_{2}$ & 0,37 & 0,53 & 0,84 & $0,58 \mathrm{p}$ \\
$\mathrm{S}_{3}$ & 0,49 & 0,60 & 1,52 & $0,87 \mathrm{p}$ \\
\hline Rerata & $0,49 \mathrm{a}$ & $0,59 \mathrm{a}$ & $0,97 \mathrm{a}$ & $(-)$ \\
\hline
\end{tabular}

Keterangan: $\mathrm{S}_{1}$ : Jerami; $\mathrm{S}_{2}$ : Enceng gondok; $\mathrm{S}_{3}$ : Seresah Kedelai; $\mathrm{I}_{1}$ : EM4; $\mathrm{I}_{2}$ : Promi; $\mathrm{I}_{3}$ : Stardec; Rerata perlakuan yang diikuti huruf yang sama menunjukkan tidak ada beda nyata pada Uji Berganda Duncan dengan taraf 5\%. Tanda (-) menunjukkan tidak ada interaksi.

Tabel 3. Ratio $\mathrm{C} / \mathrm{N}$ substrat dari masing-masing perlakuan setelah 8 minggu inkubasi

\begin{tabular}{ccccc}
\hline Limbah/Inokulum & $\mathbf{I}_{\mathbf{1}}$ & $\mathbf{I}_{\mathbf{2}}$ & $\mathbf{I}_{\mathbf{3}}$ & Rerata \\
\hline $\mathrm{L}_{1}$ & 75,03 & 79,79 & 62,79 & $72,54 \mathrm{p}$ \\
$\mathrm{L}_{2}$ & 109,07 & 89,27 & 49,08 & $82,48 \mathrm{p}$ \\
$\mathrm{L}_{3}$ & 79,56 & 51,74 & 33,82 & $55,04 \mathrm{p}$ \\
\hline Rerata & $87,89 \mathrm{a}$ & $73,60 \mathrm{a}$ & $48,56 \mathrm{a}$ & $(-)$ \\
\hline
\end{tabular}

Keterangan: $\mathrm{S}_{1}$ : Jerami; $\mathrm{S}_{2}$ : Enceng gondok; $\mathrm{S}_{3}$ : Seresah Kedelai; $\mathrm{I}_{1}$ : EM4; $\mathrm{I}_{2}$ : Promi; $\mathrm{I}_{3}$ : Stardec; Rerata perlakuan yang diikuti huruf yang sama menunjukkan tidak ada beda nyata pada Uji Berganda Duncan dengan taraf 5\%. Tanda (-) menunjukkan tidak ada interaksi

Berbeda dengan C, kadar Nitrogen sangat fluktuatif. Senyawa yang mengandung $\mathrm{N}$ mengalami perombakan, dan $\mathrm{N}$ termineralisasi menjadi ammonium $\left(\mathrm{NH}_{4+}+\right.$. Dalam kondisi yang ideal, amonium yang terbentuk merupakan sumber $\mathrm{N}$ bagi mikrobia yang terdapat dalam system dan digunakan untuk menyusun biomassa sel. Dalam kondisi seperti tersebut, maka kadar $\mathrm{N}$ total akan tetap. Namun demikian banyak faktor mempengaruhi keberadaan ammonium. Pada $\mathrm{pH}$ menuju basis, ammonium dalam kesetimbangannya akan berubah menjadi gas ammonia $\left(\mathrm{NH}_{3}\right)$. Pada kondisi aerob, ammonium mengalami nitrifikasi menjadi nitrat. Dalam kondisi 
oksigen yang terbatas, nitrat dapat mengalami denitrifikasi menjadi nitros-oksida yang selanjutnya berubah menjadi $\mathrm{N}_{2}$. Pembentukan gas $\mathrm{NH}_{3}$ maupun $\mathrm{N}_{2}$ mengakibatkan kadar $\mathrm{N}$ total menurun.

\section{KESIMPULAN}

Dari hasil penelitian ini dapat disimpulkan bahwa:

1. Pola pembentukan $\mathrm{CO}_{2}$ atau aktivitas perombakan dari ke tiga jenis inokulum sama yaitu tertinggi pada pengamatan minggu pertama, selanjutnya mengalami penurunan.

2. Total $\mathrm{CO}_{2}$ tertinggi pada substrat jerami dan seresah kedelai berturut-turut terdapat pada substrat yang diinokulasi dengan Stardec (I3) dan EM-4.

3. Kemampuan dekomposisi ke tiga inokulum yang diuji pada substrat eceng gondok rendah

4. Proses dekomposisi mengakibatkan penurunan kadar $\mathrm{C}$ dan $\mathrm{N}$

\section{DAFTAR PUSTAKA}

Barrena, R., F. Vázquez, A.S. Ferrer, 2006. The use of respiration indices in the composting process: A review. Waste Management \& Research 24(1):37-47

Crawford. J.H. 2003. Composting of Agricultural Waste in Biotechnology Applications and Research, Paul N, Cheremisinoff and R. P.Ouellette (ed). p. 68-77.

Eviati dan Sulaeman. 2009. Analisis Kimia Tanah, Tanaman, Air, dan Pupuk. Bogor: Balai Penelitian Tanah

Fitri, S. H. 2010. Estimasi Karbon Tersimpan Pada Tumbuhan Enceng Gondok Di Rawa Lebak. Prodi Biologi, Fakultas MIPA. Unlam Banjarbaru. Kalimantan Selatan

Godden, B., Ball, A.S., Helvenstein, P., McCarthy, A.J., Penninckx, M.J., 1992. Towards elucidation of the lignin degradation pathway in actinomycetes. J. Gen. Microbiol. 138, 2441-2448.

Hajama, N. 2014. Studi Pemanfaatan Enceng Gondok Sebagai Bahan Pembuatan Pupuk Kompos Dengan Menggunakan Aktivator EM-4 Dan MOL Serta Prospek Pengembangannya. Jurusan Sipil, Fakultas Teknik. Universitas Hasanuddin. Makasar

Harahap, S, M., 2008. Aplikasi Jerami Padi Untuk Perbaikan Sifat Fisik Tanah dan Produksi Padi Sawah, Tesis, SPs-USU, Medan.

Haryono. 1989. Mineralisasi Nitrogen Dua Macam Bahan Organik Pada Tiga Tingkat Pelapukan Dan Dosis Urea Serta Beberapa Aspek Yang Dipengaruhinya Pada Latosol Darmaga. Jurusan Tanah, Fakultas Pertanian. Institut Pertanian Bogor

Jorgensen, H. and L. Olsson. 2006. Production of cellulases by Penicilliumbrasilianum IBT20888 - Effect of substrateon hydrolytic performance. Enzyme and $\begin{array}{lllll}\text { Microbial } & \text { Technology. } & 38 & \text { (34): }\end{array}$ https://doi.org/10.1016/j.enzmictec.200 5.06.018

Mulyani, A., dan A. Hidayat. 2010. Kapasitas produksi bahan pangan di lahan kering. Buku: Analisis Sumberdaya Lahan Menuju Ketahanan Pangan Berkelanjutan. Penyunting: Sumarno. N. Suharta, Hermanto, Mamat HS. Badan penelitian dan 
Pengembangan Pertanian

Nurhalimah. 2017. Penggunaan Kandungan Unsur Hara Pada Enceng Gondok Dari Danau Toba. Prodi Kehutanan, Fakultas Kehutanan. Universitas Sumatera Utara. Sumatera Utara

Ponnamperuma, F. A. 1985. Straw as Source of Plant Nutrients for Wetland Rice.Pp. 117-136 in Organic Matter and Rice. Inter. Rice Res. Inst. Los Banos. Philippines.

Ratih, Y. W., L. Peniwiratri dan Nuryanto. 2018. Pengaruh Pengaturan Fase Termofil pada Pengomposan Jerami dan Sampah Pasar terhadap Perombakan Lignin dan Hasil Kompos. Prosiding Seminar Nasional Tahunan Fakultas Pertanian UNS 2 (1) $264-271$

Silva, G.T.A.; L.V. Matos; P De O Nóbrega; E F C Campello; A. S. De Resende. 2008. Chemical Composition and Decomposition Rate of Plants Used as Green Manure Gabriela. Sci. Agric. (Piracicaba, Braz.), 65: 298-305

Sivasankari, B. and D. Ravindran. A, 2016. A Study on Chemical Analysis of Water Hyacinth (Eichornia crassipes), Water Lettuce (Pistia stratiotes). DOI: 10.15680/IJIRSET.2016.0510010

Thambirajah JJ, Zukali MD, Hashim MA. 1995. Microbiological and Biochemical Changes during the Composting of Oil Palm Empty-Fruit Bunches: Effect of Nitrogen Suplementation on the Substrate. Bioresour Technol. 52:133-144.

Tuomela M, Vikman M, Hatakka A, Itavaara M. 2000. Biodegradation of Lignin in a Compost Environment: A Review. Bioresoul Technol. 72: 169-183. 